\title{
Pelatihan Pembuatan Silase Komplit Di Kelompok Wanita Tani (KWT) Mawar Desa Kuaken Kabupaten TTU-NTT
}

\author{
Gerson Frans Bira \\ Universitas Timor
}

\author{
Paulus Klau Tahuk \\ Universitas Timor
}

\author{
Asep Ikhsan Gumelar \\ Universitas Timor
}

\begin{abstract}
Livestock productivity on dry land is completely dependent on the availability of feed and season is one of the determinants of feed availability. Women Farmers Group (FWG) Mawar Kuaken Village TTU-NTT also felt the same condition. Livestock activities carried out by FWG are fattening and breeding farm and receiving rolling assistance from the local government. The main problem is that the availability of feed is very limited so that some members of the group let their livestock roam, some have to walk for kilometers and even climb tall trees to find food. For this reason, feed processing technology such as silage is needed. Silage is a feed preservation technique in an anaerobic atmosphere in a place called a silo. The purpose of the community partnership program at FWG Mawar is to train partners to be skilled in increasing the productivity of their livestock through the provision of quality feed throughout the season. The implementation method used is participatory action research, where FWG and the implementing team are jointly involved in training activities for making complete silage and assisted by students. In general, complete silage is made like any other single ingredient silage, the difference lies in the use of more complete materials and additives. The complete silage produced is of high quality, such as natural green/yellowish green, sour-scented, dense textured and does not produce mold. The nutritional content of complete silage is classified as high quality with dry matter content of $43.08 \%$, organic matter 80.15\%/DM, crude protein 13.33\%/DM, crude fat 7.12\%/DM, crude fiber 12.50\%/DM, NFE 45,35\%/DM and EM 3,112, 81 Kcal/DM with high palatability of livestock. It was concluded that the complete silage carried out by the service team and FWG Mawar could run well and produce quality complete silage, characterized by organoleptic, nutritional content and high palatability. The existence of this activity also made FWG Mawar move up a class or rank from beginner class to advanced class.
\end{abstract}

Keywords: Complete silage; FWG Mawar; participatory action research

\begin{abstract}
Abstrak
Produktivitas ternak dilahan kering sepenuhnya bergantung pada ketersediaan pakan dan musim menjadi salah satu penentu ketersediaan pakan. Kelompok Wanita Tani (KWT) Mawar Desa Kuaken TTU-NTT turut merasakan kondisi yang sama. Kegiatan peternakan yang dilakukan oleh KWT adalah penggemukan sapi dan pembibitan sapi serta mendapat bantuan perguliran dari pemerintah setempat. Masalah utamanya adalah ketersediaan pakan yang sangat terbatas sehingga sebagian anggota kelompok melepas ternak berkeliaran, sebagian harus berjalan berkilo-kilometer bahkan memanjat pohon yang tinggi untuk mencari pakan. Untuk itu diperlukan teknologi pengolahan pakan seperti silase. Silase adalah teknik pengawetan pakan pada suasana anaerob pada tempat yang disebut silo. Tujuan dari kegiatan program kemitraan masyarakat di KWT Mawar adalah melatih mitra untuk terampil dalam meningkatkan produktivitas ternaknya melalui penyediaan pakan yang berkualitas sepanjang musim. Metode pelaksanaan yang digunakan adalah participatory action research, dimana KWT dan tim pelaksana secara bersama-sama ikut terlibat dalam kegiatan pelatihan pembuatan silase komplit dan dibantu oleh mahasiswa. Umumnya silase komplit dibuat seperti silase bahan tunggal lainnya perbedaannya terletak pada penggunaan bahan dan aditif yang lebih komplit. Silase komplit yang dihasilkanpun tergolong berkualitas seperti warna hijau alami/hijau kekuningan, beraroma asam, bertekstur padat dan tidak menghasilkan jamur. Kandungan nutrisi silase komplit tergolong berkualitas dengan kandungan bahan kering 43,08\%, bahan organik 80,15\%/BK, protein kasar 13,33\%/BK, lemak kasar 7,12\%/BK, serat kasar 12,50\%/BK, BETN 45,35\%/BK dan EM 3.112, $81 \mathrm{Kkal} / \mathrm{BK}$ dengan palatabilitas ternak yang dikategorikan tinggi. Disimpulkan bahwa silase komplit yang dilakukan oleh tim pengabdian dan KWT Mawar dapat berlangsung dengan baik dan menghasilkan silase komplit
\end{abstract}

Kata kunci: Silase komplit; KWT Mawar; participatory action research 


\section{Pendahuluan}

Rendahnya produktivitas ternak di daerah lahan kering sepenuhnya bergantung pada ketersediaan pakan. Pakan sebagai sumber utama untuk meningkatkan produksi ternak sering berfluktuasi seiring perubahan musim. Pada musim hujan yang singkat sekitar 3-4 bulan ketersediaan pakan sangat tinggi namun musim kemarau yang panjang yakni 8-9 bulan pakan sangat minim. Hal ini akan berdampak pada ketersediaan pakan dalam kualitas dan kuantitasnya. Keadaan ini mengakibatkan produktivitas ternak sangat rendah apalagi pada saat musim kemarau [1]. Demikian pula Kelompok Wanita Tani (KWT) Mawar mengalami hal yang serupa yakni ketersediaan pakan yang sangat minim pada musim kemarau. KWT Mawar sendiri terletak di Desa Kuaken Kecamatan Noemuti Timur, Kabupaten Timor Tengah Utara (TTU), Nusa Tenggara Timur. Kelompok tani ini semua anggotanya terdiri dari wanita yang berprofesi sebagai petani dan peternak. Kegiatan peternakan yang dilakukan oleh KWT adalah penggemukan dan pembibitan sapi bali serta mendapat bantuan perguliran dari pemerintah setempat. Penggemukan dan pembibitan sapi yang selama ini dilakukan kelompok ini cukup lama yakni 2-4 tahun dan hal ini cukup memprihatinkan karena dengan pemeliharaan yang cukup lama namun hasil penjualan tidak optimal dan perguliran ternak akan berlangsung lama. Masalah utamanya adalah ketersediaan pakan yang sangat terbatas dimusim kemarau sehingga sebagian anggota kelompok melepas ternak berkeliaran untuk mencari pakannya sendiri, sebagian anggota KWT juga harus berjalan berkilo-kilometer bahkan memanjat pohon yang tinggi untuk mencari pakan. Dari keadaan-keadaan yang demikian maka diperlukan upaya-upaya untuk menyediakan pakan yang ketersediaanya tetap sepanjang waktu.

Ketersediaan pakan dapat dilakukan dengan memanfaatkan kelebihan pakan pada musim hujan untuk dapat dimanfaatkan pada musim paceklik yakni dengan metode silase. Silase dapat dibuat dari bahan tunggal dan variasi bahan atau sering dikenal sebagai silase komplit. Silase komplit merupakan metode pengawetan pakan hijauan pada kondisi anerob dengan mencampurkan berbagai jenis bahan (rumput, legum dan aditif) dan disimpan dalam wadah yang disebut silo [2] Silase komplit dapat disimpan pada waktu yang cukup lama (5-6 bulan) dan mampu memenuhi kebutuhan hidup pokok maupun kebutuhan produksi. Proses pembuatan silase komplit juga tergolong mudah dengan tetap mengikuti prinsip-prinsip dalam pembuatannya seperti harus menciptakan kondisi anaerob semaksimal mungkin. Adanya penerapan silase komplit ini maka kebutuhan ternak akan terpenuhi disepanjang musim, peternak tidak perlu berjalan jauh untuk mencari pakan dan ternak dapat diikat/dikandangkan (intensif).Tujuan utama dari kegiatan program kemitraan masyarakat di KWT Mawar adalah melatih mitra untuk terampil dalam meningkatkan produktivitas ternaknya melalui penyediaan pakan yang berkualitas sepanjang musim. Produktivitas ternak yang tinggi akan turut meningkatkan kesejahteraan mitra.

\section{Metode Pelaksanaan}

Metode yang digunakan dalam kegiatan ini yaitu metode participatory action research. KWT dan tim pelaksana dengan bantuan mahasiswa secara bersama-sama ikut terlibat dalam kegiatan pelatihan pembuatan silase komplit. Adapun tahapan-tahapan kegiatan dalam mengatasi permasalahan mitra yaitu: (1) Persiapan. Persiapan yang dimaksudkan adalah tim pelaksana bersama mitra menentukan jadwal dan waktu yang tepat untuk pelaksanaan kegiatan sehingga dapat menjawab dan mengatasi permasalahan yang telah dirancangkan pada diskusi awal; (2) Pelatihan dan pembuatan silase komplit. Pelatihan dan pendampingan oleh tim pelaksana yang sekaligus praktek secara langsung dengan tujuan meningkatkan pengetahuan dan pemahaman mitra; dan (3) Pengujian kualitas silase secara organoleptik, proksimat dan palatabilitas 


\section{Hasil dan Pembahasan}

\subsection{Prosedur Pembuatan Silase Komplit}

Umumnya silase komplit dibuat seperti silase bahan tunggal lainnya perbedaannya terletak pada penggunaan bahan dan aditif yang lebih komplit. Hijauan yang digunakan dalam membuat silase komplit ini terdiri dari leguminosa seperti hijauan gamal (Gliricidia sepium), lamtoro (Leucaena leucocephala), rumput lapangan, dan aditif berupa dedak padi dan tepung jagung. Penggunaan legum dan rumput didasarkan pada ketersediaan yang melimpah pada musim hujan. Proses pembuatannya yakni hijauan yang terdiri dari legum (gamal dan lamtoro) dan rumput lapangan dipotong pada masa sebelum berbunga dan diangin-anginkan selama \pm 3 jam untuk menurunkan kadar air. Kadar air hijauan perlu untuk dikurangi agar proses fermentasi dapat berjalan dengan normal dan resiko pembusukan karena kandungan air yang terlalu tinggi dapat dicegah. Setelah kadar air bahannya berkurang dilanjutkan dengan pencacahan menggunakan mesin pencacah (Gambar 1). Hasil dari cacahan tersebut ditimbang dengan perbandingan 40:40 untuk legum dan rumput dan dicampur merata. Kemudian menimbang aditif berupa dedak padi dan tepung jagung dengan perbandingan 10:10 dan ditaburkan pada hijauan yang sudah tercampur (Gambar 2). Campuran tersebut kemudian diaduk secara merata sampai homogen dan dimasukkan dalam silo (drum plastik kapasitas $150 \mathrm{~kg}$ ) secara perlahan sambil ditekan dengan tujuan mengeluarkan udara yang ada didalam silo (Gambar 3). Setelah terisi penuh silo ditutup dan disimpan selama 21 hari (Gambar 4). Penyimpanan silase diusahakan tidak terkena matahari secara lansung sehingga disarankan disimpan dibawah naungan. Proses fermentasi silase memakan waktu sedikitnya 21 hari untuk mencapai hasil yang optimal[3]. Selanjutnya silo dibuka dan dilakukan penilaian secara organoleptik, pemeriksaan kandungan nutrisi dan uji palatabilitas terhadap ternak.

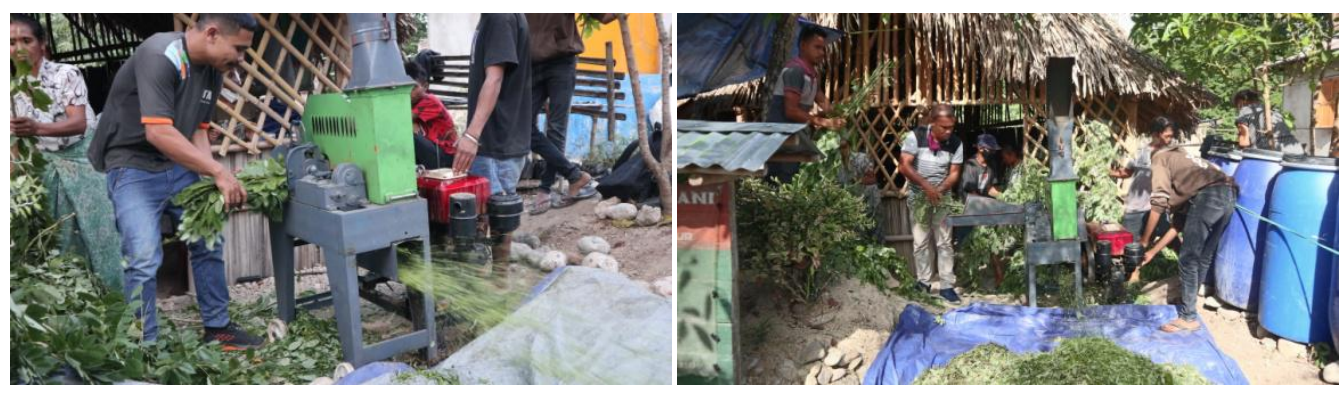

Gambar 1. Pencacahan Hijauan menggunakan mesin cacah

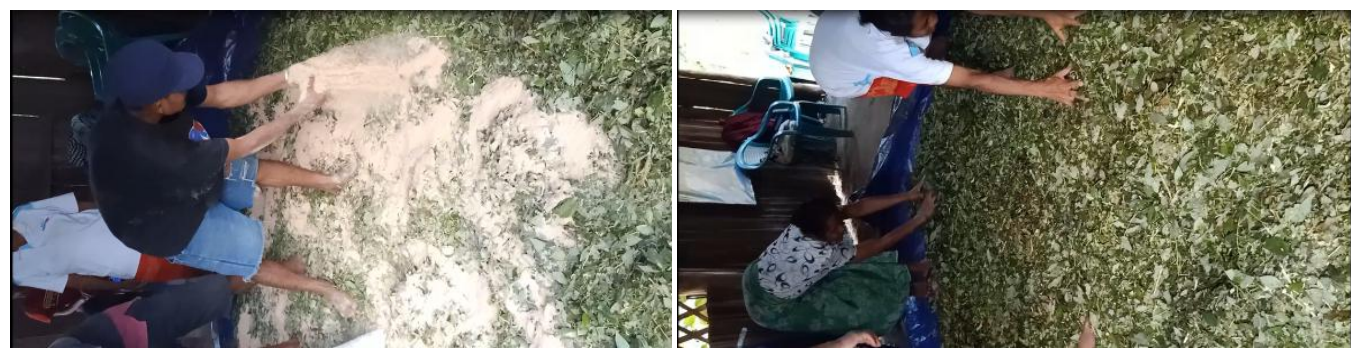

Gambar 2. Pencampuran aditif dengan hijauan 


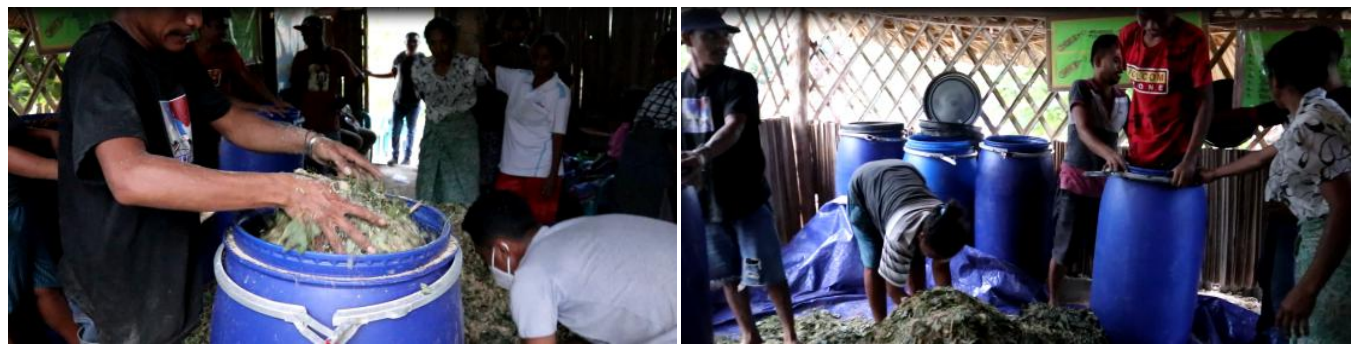

Gambar 3. Proses pengisian hijauan dan aditif kedalam silo
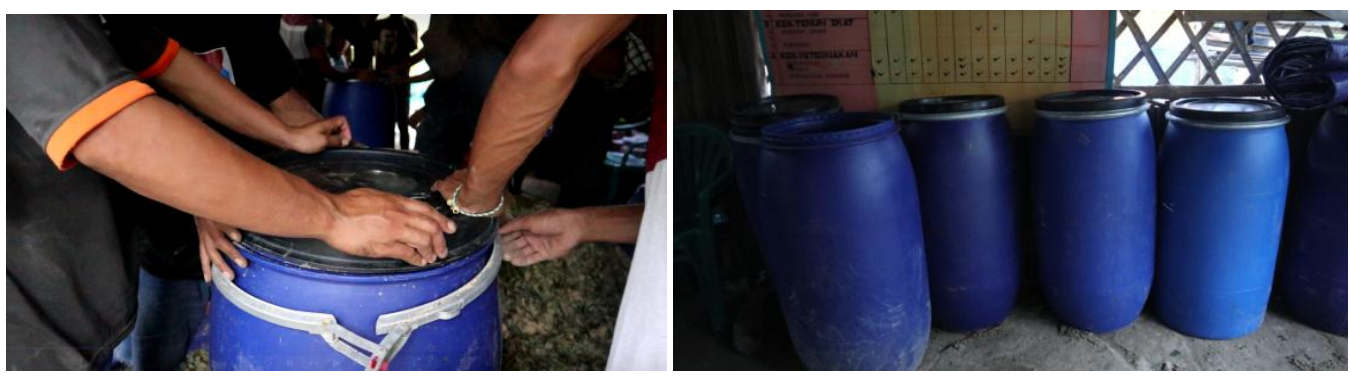

Gambar 4. Penutupan dan penyimpanan (ensilase) selama 21 hari

\subsection{Kualitas organoleptik silase komplit}

Salah satu metode penilaian kualitas silase komplit dapat diamati secara organoleptik seperti warna, aroma, tekstur dan keberadaan jamur. Penyebab kegagalan dalam pembuatan silase dapat dipengaruhi oleh beberapa faktor seperti proses pembuatan yang salah, kondisi anaerob yang tidak tercipta serta minimnya ketersediaan karbohidrat mudah larut[4]. Kualitas organoleptik silase komplit yang dibuat oleh tim pelaksana dan KWT Mawar tersaji pada Tabel 1.

Tabel 1. Kualitas Organoleptik Silase Komplit

\begin{tabular}{ll}
\hline Indikator & Kualitas organoleptik \\
\hline Warna & Hijauan alami atau hijau kekuningan \\
Aroma & Asam \\
Tekstur & Padat \\
Keberadaan jamur & Tidak ada \\
\hline
\end{tabular}

Tabel 1 menunjukkan bahwa silase komplit yang dibuat oleh tim pengabdian dan KWT mawar menghasilkan silase yang berkualitas berdasarkan organoleptiknya. Dari organoleptik yang ada memberikan gambaran bahwa proses ensilase (fermentasi) berjalan dengan optimal. Hasil ini didukung dari berbagai literatur bahwa silase yang berkualitas memiliki warna hijau alami atau hijau kekuningan[5]. Perubahan warna pada silase pada saat proses fermentasi terjadi pelepasan oksigen sehingga gula pada tanaman akan teroksidasi dan mengakibatkan temperatur menjadi naik sehingga warna akan berubah. Penampakkan organoleptik silase komplit yang dibuat terlihat pada Gambar 5. Dari Gambar 5 menjelaskan bahwa silase komplit yang dihasilkan tergolong berkualitas dengan warna, tekstur, aroma dan tidak ditumbuhi jamur pembusuk yang sudah sesuai dengan silase yang berkualitas.

Aroma silase komplit yang dihasilkan dalam kegiatan pengabdian juga termasuk dalam kategori silase yang berkualitas karena menghasilkan aroma khas silase yakni beraroma asam. Aroma asam yang dihasilkan berasal dari bakteriasam laktat yang terbentuk selama proses fermentasi berlangsung.Untuk memacu pertumbuhan dan kinerja dari bakteri asam laktat dibutuhkan sumber karbohidrat mudah larut dan dalam kegiatan pengabdian ini sumber 
karbohidrat mudah larut yang digunakan adalah dedak padi dan tepung jagung. Silase komplit yang dihasilkan bertekstur padat dan dikategorikan sebagai silase yang berkualitas[6]. Tekstur silase akan menjadi lembek dan tidak menggumpal apabila adanya udara dalam silo dan kadar air dalam hijauan yang masih tinggi. Hal yang sama pada tingkat keberadaan jamur, dimana hasilnya tidak menunjukkan adanya jamur yang tumbuh pada silase komplit. Umumnya tumbuhnya jamur dapat disebabkan karena masih adanya oksigen yang berada dalam silo. Adanya oksigen ini diakibatkan dari tingkat kepadatan bahan dalam silo yang masih menyisakan ruangan serta jenis silo yang digunakan. [7] menyatakan bahwa untuk menghindarkan dari bakteri pembusuk pada silase maka diperlukan tambahan aditif yang akan merangsang tumbuhnya bakteri asam laktat. Dari aspek organoleptik ini menjelaskan bahwa proses pembuatan silase berlangsung dengan normal.

Silase komplit merupakan salah satu teknologi pakan yang cukup sederhana yang dapat dimanfaatkan pada saat kekurangan pakan. Kelebihan hijauan pakan pada musim penghujan dapat diawetkan dan digunakan pada musim kemarau. Salah satu yang sangat mempengaruhi silase komplit adalah penggunaan silo. Silo yang digunakan dalam kegiatan ini berupa drum plastik dengan kapasitas $150 \mathrm{~kg}$. Penggunaan drum ini cukup mempermudah anggota KWT agar dapat dipindah-pindahkan ke tempat yang diinginkan. KWT Mawar merupakan kumpulan wanita (ibu rumah tangga) yang mendapat bantuan ternak sapi bibit dan kemudian akan digulirkan pada masyarakat lainnya. Adanya kegiatan ini pun turut membantu KWT agar produktivitas ternak dapat tercapai secara maksimal. Nilai tambah bagi KWT Mawar adalah dengan adanya kegiatankegiatan yang dilakukan oleh tim pengabdian memberikan nilai positif bagi KWT mawar, dimana sebelum kegiatan KWT Mawar berada pada tingkatan kelas pemula untuk kelompok tani namun setelah kegiatan berlangsung KWT Mawar berubah ke kelas lanjut (menunggu waktu pengukuhan).


Gambar 5. Silase komplit

\subsection{Kandungan nutrisi silase komplit}

Kandungan nutrisi silase merupakan salah satu parameter untuk dapat mengetahui kualitas silase komplit. Untuk mengetahui kandungan nutrisi dari silase komplit yang telah dibuat maka dilakukan analisis laboratorium secara proksimat. Hasil analisis proksimat terhadap silase komplit terlihat pada Tabel 2.

Tabel 2. Kandungan Nutrisi Silase Komplit

\begin{tabular}{lrl}
\hline Parameter & \multicolumn{2}{l}{ Nilai Parameter } \\
\hline Bahan Kering & 43,08 & $(\%)$ \\
Bahan Organik & 80,15 & $(\% \mathrm{BK})$ \\
Protein Kasar & 13,33 & $(\% \mathrm{BK})$ \\
Lemak Kasar & 7,12 & $(\% \mathrm{BK})$ \\
Serat Kasar & 12,50 & $(\% \mathrm{BK})$ \\
Bahan ekstrak Tanpa Nitrogen $* *$ & 45,35 & $(\% \mathrm{BK})$ \\
Energi Metabolis ** & $3.112,81$ & $(\mathrm{Kkal} / \mathrm{kg} \mathrm{BK})$ \\
\hline
\end{tabular}

Keterangan : Hasil analisis laboratorium kimia pakan Fakultas Peternakan Universitas Nusa Cendana (2021). **Perhitungan dari parameter 
Berdasarkan Tabel 2 menunjukkan bahwa kandungan nutrisi silase komplit yang dihasilkan cukup optimal bagi kebutuhan ternak ruminansia. Adanya sumber karbohidrat (aditif) seperti dedak padi dan tepung jagung maka bahan kering akan semakin menurun[8]. Hal ini sebagai akibat dari kemampuan bakteri asam laktat yang tumbuh dalam proses ensilase dan memanfaatkan karbohidrat terlarut sehingga menciptakan kondisi asam dan mencegah bertumbuhnya bakteri pembusuk[9]. Hal yang sama juga pada bahan organik yang dihasilkan termasuk tinggi, sebagai akibat dari hijauan yang digunakan serta tambahan aditif yang merangsang tumbuhnya bakteri asam laktat.

Protein kasar silase komplit yang dihasilkan termasuk tinggi dan lebih tinggi dari bahan silase tunggal. Dimana jika bahan silase tunggal dari daun gamal hanya menghasilkan kandungan protein kasar silase rumput odot 12,72\% [10], silase daun gamal 10,84\% [11] dan silase rumput raja berkisar 7,57-10,77\% (Hidayat, 2021). Demikian pula lemak kasar, serat kasar, bahan ekstrak tanpa nitrogen dan energi metabolis yang tergolong tinggi. Dari nilai kandungan nutrisi ini memberi gambaran bahwa silase komplit yang dibuat oleh tim pelaksana dan KWT mawar dikategorikan tinggi dan memenuhi kriteria silase yang normal dan dapat memenuhi kebutuhan ternak.Pada dasarnya pembuatan silase melewati beberapa fase dimulai dari fase yakni fase aerob, fase fermentasi, fase stabil dan fase pengeluaran [12]. Jika fase-fase ini dapat dilakukan dan dilewati dengan baik maka otomatis silase yang dihasilkan akan berkualitas.

\subsection{Nilai palatabilitas}

Palatabilitas adalah tingkat kesukaan yang ditunjukkan oleh ternak untuk mengkonsumsi suatu bahanpakan yang diberikan dalam periode tertentu[13]. Palatabilitas menggambarkan tingkat kesukaan ternak terhadap silase komplit yang dibuat. Silase komplit yang dipanen (21 hari), silo dibuka dan diangin-anginkan untuk mengurangi aroma asam pada silase. Kemudian diberikan ke ternak milik KWT Mawar. Aplikasi langsung pada ternak milik KWT diharapkan dapat memberikan semangat kerja bagi KWT untuk tetap membuat silase komplit. Berdasarkan uji palatabilitas (Gambar 6), memberikan penjelasan bahwa walaupun baru kali pertama ternak diberikan silase komplit langsung dikonsumsi dan ini menjelaskan bahwa palatabilitas dari silase komplit cukup tinggi.

Palatabilitas lebih dipengaruhi oleh kenampakan dari pakan itu sendiri. Kenampakan lebih didasarkan pada tekstur, warna, bentuk pakan, aroma, rasa dan suhu. Dilihat dari organoleptik silase komplit yang dibuat maka akan turut meningkatkan palatabilitas. Tekstur padat, beraroma asam serta memiliki warna hijau alami atau hijau kekunigan pada silase komplit yang dibuat merangsang ternak untuk mengkonsumsinya tanpa menolak.



Gambar 6. Palatabilitas 


\section{Kesimpulan}

Berdasarkan kegiatan-kegiatan yang telah dilakukan maka dapat disimpulkan bahwa pembuatan silase komplit yang dilakukan oleh tim pengabdian dan KWT Mawar dapat berlangsung dengan baik dan menghasilkan silase komplit yang berkualitas, ditandai dengan organoleptik, kandungan nutrisi serta palatabilitas yang tinggi. Adanya kegiatan ini juga membuat KWT Mawar naik kelas atau peringkat dari kelas pemula menjadi kelas lanjut. Harapan besar dari KWT Mawar agar pendampingan terus dilakukan oleh tim pengabdi agar KWT Mawar menjadi kelompok tani yang mandiri dan mampu untuk tetap aktif dalam peningkatan perekonomian keluarga lewat pertanian/peternakan.

\section{Ucapan Terima Kasih}

Ucapan terima kasih kepada Direktorat Riset dan Pengabdian Masyarakat (DRPM) Kementerian Riset dan Teknologi/Badan Riset dan Inovasi Nasional sebagai penyandang dana dengan Nomor Kontrak 081/SP2H/PPM/DRPM/2021, dan kelompok Wanita Tani (KWT) yang telah menerima tim pelaksana sebagai mitra.

\section{Daftar Pustaka}

Abrar, A., A. Fariani dan Fatonah. 2019. Pengaruh Proporsi bagian Tanaman terhadap Kualitas Fisik Silase Rumput Gajah (Pennisetum Purpureum). Jurnal Peternakan Sriwijaya, 8 (1) : 2127. https://doi.org/10.33230/JPS.8.1.2019.9379

Bira, G.F., P.K Tahuk., K.W. Kia., S.K Hartun dan F. Nitsae. 2020. Karakteristik Silase Semak Bunga Putih (Chromolaena odorata) dengan Penambahan Jenis Karbohidrat Terlarut yang Berbeda. Jurnal Sain Peternakan Indonesia, 15 (4) : 367-374. https://doi.org/10.31186 /jspi.id.15.4.367-374

Bolsen. K.K. and D.A. Sapienza, 1993. The Tecnology of Silage . International.Inc. Kansas State University.

Christi, R.F., A. Rochana dan I. Hernaman. Kualitas fisik dan palatabilitas konsentrasi fermentasi dalam ransum kambing perah peranakan ettawa. Jurnal Ilmu Ternak, 18 (2) : 121-125. https://doi.org/10.24198/jit.v18i2.19461

Departemen Pertanian. 1980. Silase sebagai makanan ternak. Departemen Pertanian.Balai Informasi Pertanian. Laporan Penelitian Ternak. Ciawi, Bogor.

Kartadisastra, H. R. 1997. Penyediaan danPengelolaan Pakan Ternak Ruminansia (Sapi, Kerbau, Domba, Kambing). Kanisius, Yogyakarta.

Nahak, O.R., P.K. Tahuk., G.F. Bira., A. Bere dan H. Riberu. 2019. Pengaruh Penggunaan Jenis Aditif yang Berbeda terhadap Kualitas Fisik dan Kimia Silase Komplit Berbahan Dasar Sorgum (Shorgum bicolor (L.) Moench). Journal of Animal Science (JAS), 4 (1) : 3-5. https://doi.org/10.32938/ja.v4i1.649

Nur Kholis, D.L. Rukmi dan Y. Mariani. 2018. Penggunaan Bakteri Lactobacillus plantarum Pada Silase Kulit Pisang Kepok (Musa paradisiaca. L) Sebagai Pakan Ternak. Jurnal Imu Peternakan Terapan, 2 (1) : 6-12. https://doi.org/10.25047/jipt.v1i2.891

Ridwan, R., S. Ratnakomala., G. Kartina dan Y.Widyastuti. 2005. Pengaruh Penambahan Dedak Padi dan Lactobacillus plantarum1BL-2 dalam Pembuatan Silase Rumput Gajah (Pennisetum Purpureum). MediaPeternakan, 28 (3) : 117-123.

Utomo, R., S.P.S. Budhi dan I.F. Astuti. 2013. Pengaruh Level Onggok Sebagai Aditif Terhadap Kualitas Silase Isi Rumen Sapi. Buletin Peternakan, 37 (3): 173-180. https://doi.org/10.21059/buletinpeternak.v37i3.3089

Tahuk, P.K and A. Dethan. 2010. Performance Of Bali Bull In Greenlot Fattening By Farmers When Rainy Season In Timor Island. Journal Indonesian Tropical Animal Agriculture, 35 (4) : 257-261. https://doi.org/10.14710/jitaa.35.4.257-261 
Tahuk, P.K., G.F. Bira and H. Taga. 2020. Physical Characteristics Analysis of Complete Silage Made of Sorghum Forage, King Grass and Natural Grass. International Conference: Improving Tropical Animal Production for Food Security, IOP Conf. Series: Earth and Environmental Science 465 (2020) 012022. https://doi.org/10.1088/1755-1315/465/1 /012022

Tahuk, P.K and G.F. Bira. 2020. Carcass and meat characteristics of male Kacang goat fattened by complete silage. Veterinary World, 13 (4) : 706-715. https://dx.doi.org/10.14202 /vetworld.2020.706-715

Tahuk, P.K dan G.F. Bira. 2021. Pelatihan Pembuatan Silase Gamal (Gliricidia sepium) dalam mengatasi kekurangan pakan di Desa Kuaken Kecamatan Noemuti Timur Kabupaten TTU. Bakti cendana, 4 (1) : 44-51. https://doi.org/10.32938/bc.v4i1

Wati, W.S., Mashudi dan A. Irsyamawati. 2018. Kualitas Silase Rumput Odot (Pennisetum purpureumcv. Mott) dengan Penambahan Lactobacillus plantarum dan MolassesPada Waktu Inkubasi Yang Berbeda. Jurnal Nutrisi Ternak Tropis, 1 (1) : 45-53. https://doi.org/10.21776 /ub.jnt.2018.001.01.6

Hidayat, N. 2014. Karakteristik dan Kualitas Silase Rumput Raja Menggunakan Berbagai Sumber dan Tingkat Penambahan Karbohidrat Fermentable. Agripet. 14 (1) : 42-49. https://doi.org /10.17969/agripet.v14i1.1204

Widyastuti, Y. 2008. Fermentasi silase dan manfaat probiotik silase bagi ruminansia. Media Peternakan, 31 (3) : 225-232.

\section{Afiliasi:}

Gerson Frans Bira*, Paulus Klau Tahuk, Asep Ikhsan Gumelar

Fakultas Pertanian, Universitas Timor, Kefamenanu

Jalan Km. 09, Kelurahan Sasi, Kecamatan Kota Kefamenanu, Kabupaten TTU, Provinsi NTT, 85613

Email: gersonbira@yahoo.co.id*,paulklau@yahoo.co.id,gumelar.ikhsan@yahoo.co.id 